\title{
Electrochemical Properties of Robson Type Macrocyclic Dicopper(II) Complexes
}

\author{
Elisabete C.B.A. Alegria, ${ }^{a, b, *}$ Sellamuthu Anbu, ${ }^{b}$ \\ Luísa M.D.R.S. Martins ${ }^{a, b}$ and Armando J.L. Pombeiro ${ }^{b, *}$ \\ ${ }^{a}$ Chemical Engineering Department, ISEL-Instituto Superior de Engenharia de Lisboa, Instituto \\ Politécnico de Lisboa, 1959-007 Lisboa, Portugal \\ ${ }^{b}$ Centro de Química Estrutural, Instituto Superior Técnico, Universidade de Lisboa, Av. Rovisco \\ Pais, 1049-001 Lisboa, Portugal
}

Received 22 July 2015; accepted 22 August 2015

\begin{abstract}
The redox properties of the 1,10-phenanthroline containing Robson type symmetrical macrocyclic dicopper(II) complex $\left[\mathrm{Cu}_{2} \mathrm{~L}\left(\mathrm{H}_{2} \mathrm{O} \text {.phen }\right)_{2}\right]\left(\mathrm{ClO}_{4}\right)_{2} \mathbf{1}(\mathrm{L}=\mu$-11,23-dimethyl3,7,15,19-tetraazatricyclo-[19.3.1.18 19,13,21] he p t a c o s a-1(24), 2, 7, 9, 11, 13(26), 14, 19, 21(25), 22-decaene-25,26-diolate) and of its dicopper(II) precursor $\left[\mathrm{Cu}_{2} \mathrm{~L}\left(\mathrm{H}_{2} \mathrm{O}\right)_{2}\right]\left(\mathrm{ClO}_{4}\right)_{2} 2$ have been investigated by cyclic voltammetry and controlled potential electrolysis in different organic solvents. They exhibit two consecutive reversible one-electron reductions assigned to the $\mathrm{Cu}^{\mathrm{II}} \mathrm{Cu}^{\mathrm{II}} \rightarrow \mathrm{Cu}^{\mathrm{I}} \mathrm{Cu}^{\mathrm{II}} \rightarrow \mathrm{Cu}^{\mathrm{I}} \mathrm{Cu}^{\mathrm{I}}$ cathodic processes. The results suggest that, in solution, phenanthroline does not coordinate to the metal in complex $\mathbf{1}$, but its H-bonding interaction with the water ligands can be preserved.
\end{abstract}

Keywords: Robson type macrocyclic dicopper(II) complexes, 1,10-phenanthroline, cyclic voltammetry, controlled potential electrolysis.

\section{Introduction}

The presence of metal-binding sites in DNA structure makes it a good target for metal-containing drugs, since it plays a central role in replication, transcription and regulation of genes [1-3].

Over the past few decades, several phenanthroline based mononuclear $\mathrm{Cu}$ (II) complexes were synthesized and their interactions with DNA and cytotoxic activities [1-3] were reported. These works are mainly limited to mononuclear

\footnotetext{
*Corresponding author. E-mail address: ebastos@deq.isel.ipl.pt; pombeiro@ist.utl.pt.
} 
complexes and very few studies on dinuclear complexes with metal ions in close proximity were reported to date [4,5]. Recently, some of us synthesized phenanthroline based dicopper(II) complexes, which strongly bind to DNA and also regulate apoptosis [6,7]. In this context, a novel phenanthroline containing Robson type symmetrical macrocyclic dicopper(II) complex $\left[\mathrm{Cu}_{2} \mathrm{~L}\left(\mathrm{H}_{2} \mathrm{O} \text {.phen }\right)_{2}\right]\left(\mathrm{ClO}_{4}\right)_{2} \mathbf{1}$ was obtained by reacting the reported Robson type macrocyclic precursor dicopper(II) complex $\left[\mathrm{Cu}_{2} \mathrm{~L}\left(\mathrm{H}_{2} \mathrm{O}\right)_{2}\right]\left(\mathrm{ClO}_{4}\right)_{2} 2$ and 1,10phenanthroline in ethanol [8]. X-ray crystallography reveals that, in the solid state, 1,10-phenantroline nitrogens interact with the copper(II) centres through $\mathrm{H}$ bonds with the coordinated water. However, analytical, UV-vis, ESI-MS and EPR spectral data suggest that the 1,10-phenanthroline molecules are replacing the coordinated water molecules in $\mathbf{2}$, affording a 1,10-phenanthroline coordinated macrocyclic dicopper(II) complex in solution with a different metal coordination geometry. Nevertheless, this matter has not been fully clarified [8].

The catalytic activity of complexes $\mathbf{1}$ and $\mathbf{2}$ towards the hydrolysis of 4 nitrophenyl phosphate, DNA binding, cleavage and preliminary anticancer properties was studied [8]. Complex 1 displays better DNA binding and significant cleavage activity than 2 . The influence of the phenanthroline moiety on the phosphate hydrolysis, DNA binding, cleavage and anticancer properties of complex $\mathbf{1}$ has also been studied. The dicopper(II) complexes $\mathbf{1}$ and $\mathbf{2}$ showed cytotoxicity in human cervical HeLa cancer cells, giving IC 50 values of 15.82 and $79.41 \mu \mathrm{M}$, respectively. Antiproliferative effect of $\mathbf{1}$ and $\mathbf{2}$ were confirmed by Trypan blue Exclusive assay and lactate dehydrogenase level in HeLa cancer cell lysate and content media [8].

Herein we report the electrochemical properties of complexes $\mathbf{1}$ and $\mathbf{2}$ using cyclic voltammetry $(\mathrm{CV})$ and controlled potential electrolysis (CPE) techniques, aiming also to further contribute to clarify the structure of $\mathbf{1}$ in solution, namely the eventual replacement (or not) of the water ligands by phenanthroline molecules.

\section{Results and discussion}

The redox properties of the compounds $\left[\mathrm{Cu}_{2} \mathrm{~L}\left(\mathrm{H}_{2} \mathrm{O} \text {.phen }\right)_{2}\right]\left(\mathrm{ClO}_{4}\right)_{2} \mathbf{1}$ and $\left[\mathrm{Cu}_{2} \mathrm{~L}\left(\mathrm{H}_{2} \mathrm{O}\right)_{2}\right]\left(\mathrm{ClO}_{4}\right)_{2} \quad 2$ (Scheme 1) have been investigated by cyclic voltammetry $(\mathrm{CV})$, at a Pt electrode, in various organic solvents, using a $0.2 \mathrm{M}$ $\left[{ }^{n} \mathrm{Bu}_{4} \mathrm{~N}\right]\left[\mathrm{BF}_{4}\right]$ solution, at $25^{\circ} \mathrm{C}$. Results are summarized in Table 1 and Fig. 1.

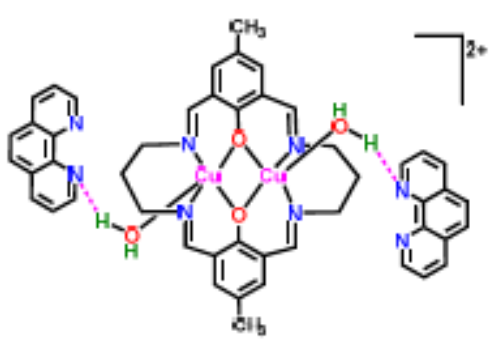

1



2

Scheme 1 
Table 1. Cyclic voltammetric data ${ }^{a}$ for complexes $\left[\mathrm{Cu}_{2} \mathrm{~L}\left(\mathrm{H}_{2} \mathrm{O} \text {.phen }\right)_{2}\right]\left(\mathrm{ClO}_{4}\right)_{2} \mathbf{1}$ and $\left[\mathrm{Cu}_{2} \mathrm{~L}\left(\mathrm{H}_{2} \mathrm{O}\right)_{2}\right]\left(\mathrm{ClO}_{4}\right)_{2} 2$ in various organic solvents.

\begin{tabular}{|c|c|c|c|c|}
\hline Solvent & $\begin{array}{c}\left({ }^{\mathrm{I}} E_{1 / 2}{ }^{\text {red }}\right) \text { or }{ }^{\mathrm{I}} E_{\mathbf{p}}{ }^{\text {red }} \\
\left(\mathbf{I}^{\mathrm{red}}\right)\end{array}$ & $\begin{array}{c}\left({ }^{\mathrm{II}} E_{1 / 2}{ }^{\mathrm{red}}\right) \text { or }{ }^{\mathrm{II}} E_{\mathrm{p}} \text { red } \\
\left(\mathrm{II}^{\mathrm{red}}\right)\end{array}$ & $\Delta E(\mathbf{V})$ & $K_{\mathrm{c}}$ \\
\hline \multicolumn{5}{|c|}{1} \\
\hline $\begin{array}{c}\text { DMSO } \\
\text { DMF } \\
\mathrm{NCMe} \\
\mathrm{MeOH} \\
\mathrm{EtOH} \\
\end{array}$ & $\begin{array}{c}(-0.44) \\
(-0.42) \\
(-0.36) \\
(-0.40) \\
-0.41 \\
\end{array}$ & $\begin{array}{c}(-0.87) \\
(-0.85) \\
-0.86 \\
-0.82 \\
- \\
\end{array}$ & $\begin{array}{c}0.43 \\
0.43 \\
0.50 \\
0.42 \\
- \\
\end{array}$ & $\begin{array}{c}1.9 \times 10^{7} \\
1.9 \times 10^{7} \\
- \\
- \\
-\end{array}$ \\
\hline \multicolumn{5}{|c|}{2} \\
\hline $\begin{array}{c}\text { DMSO } \\
\text { DMF } \\
\text { NCMe } \\
\text { MeOH } \\
\text { EtOH }\end{array}$ & $\begin{array}{c}(-0.48) \\
(-0.46) \\
(-0.39) \\
(-0.45) \\
-0.44\end{array}$ & $\begin{array}{c}(-0.91) \\
(-0.89) \\
-0.91 \\
-0.84 \\
-0.86\end{array}$ & $\begin{array}{l}0.43 \\
0.43 \\
0.52 \\
0.39 \\
0.42\end{array}$ & $\begin{array}{c}1.9 \times 10^{7} \\
1.9 \times 10^{7} \\
- \\
- \\
-\end{array}$ \\
\hline
\end{tabular}

${ }^{a}$ Values in $\mathrm{V} \pm 0.02$ relative to SCE; they can be converted to the NHE reference by adding $0.245 \mathrm{~V}$; scan rate of $200 \mathrm{mV} \mathrm{s}^{-1}$; values for reversible waves are given in brackets.
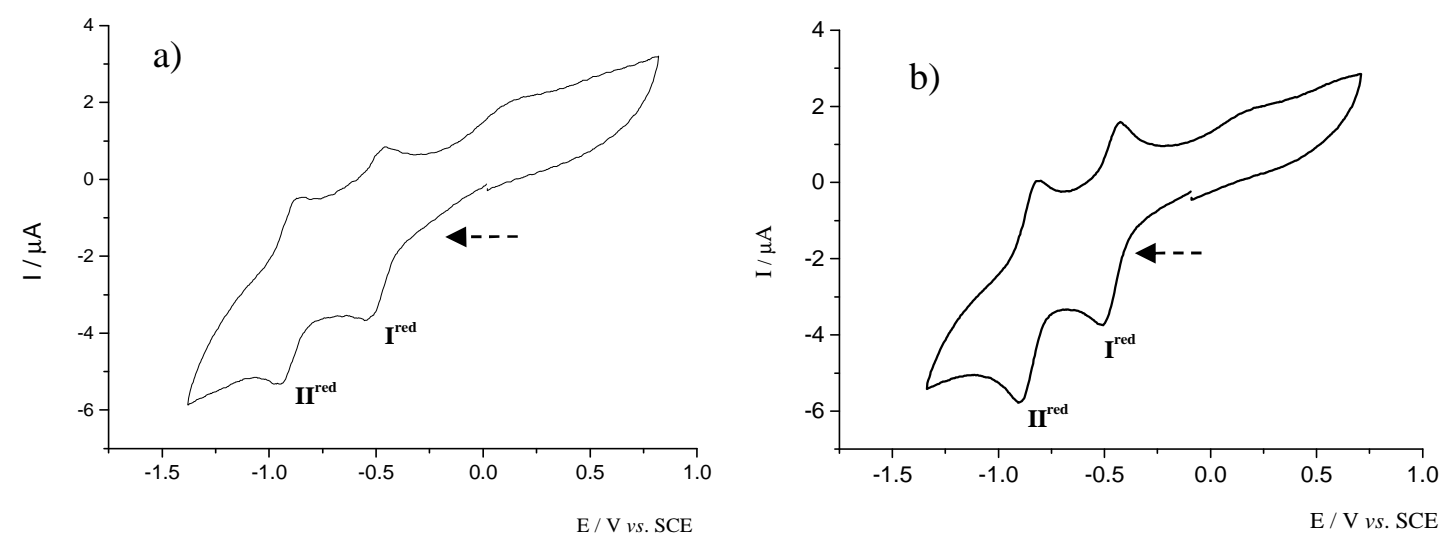

Figure 1. Cyclic voltammogram of $\left[\mathrm{Cu}_{2} \mathrm{~L}\left(\mathrm{H}_{2} \mathrm{O} \text {.phen }\right)_{2}\right]\left(\mathrm{ClO}_{4}\right)_{2} \quad \mathbf{1}$ (a) and $\left[\mathrm{Cu}_{2} \mathrm{~L}\left(\mathrm{H}_{2} \mathrm{O}\right)_{2}\right]\left(\mathrm{ClO}_{4}\right)_{2} 2$ (b) in a $0.2 \mathrm{M}\left[{ }^{n} \mathrm{Bu}_{4} \mathrm{~N}\right]\left[\mathrm{BF}_{4}\right] / \mathrm{DMF}$ solution, at a Pt disc working electrode $(d=1 \mathrm{~mm})$, run at a scan rate of $200 \mathrm{mVs}^{-1}$.

The cyclic voltammograms of these dicopper(II) complexes exhibit a first singleelectron reversible (in DMSO, DMF, NCMe and $\mathrm{MeOH}$ ) or irreversible (in $\mathrm{EtOH}$ ) reduction wave (see wave $\mathbf{I}^{\text {red }}$, Fig. $\mathbf{1}$, for $\mathbf{1}$ and $\mathbf{2}$ in DMF, Table 1) and, at a lower potential, a second single-electron reversible (in DMSO and DMF) or irreversible (in $\mathrm{NCMe}, \mathrm{MeOH}$ and $\mathrm{EtOH}$ ) reduction (see wave II ${ }^{\text {red }}$, Fig. 1, for $\mathbf{1}$ and 2 in DMF), at the reduction potential values given in Table $1{ }^{\mathrm{I}} E_{\mathrm{p}}^{\mathrm{red}}$ in the range from -0.36 to $-0.48 \mathrm{~V} v s$. SCE, and ${ }^{\mathrm{II}} E_{\mathrm{p}}^{\text {red }}$ between -0.82 and $-0.91 \mathrm{~V} v s$. SCE).

The occurrence of single-electron reductions ( $\mathbf{I}^{\text {red }}$ and $\left.\mathbf{I I}^{\text {red }}\right)$ has been confirmed by exhaustive controlled potential electrolysis (CPE) at a potential slightly 
cathodic to that of the peak potential of wave $\mathbf{I}^{\text {red }}$ or $\mathbf{I I}^{\text {red }}$. CPE at any of the reduction waves corresponds to a charge consumption of $1 \mathrm{~F} /$ mole of complex.

The above observations can be rationalized, for reversible waves, by Scheme 2, involving the stepwise $\mathrm{Cu}^{\mathrm{II}} \rightarrow \mathrm{Cu}^{\mathrm{I}}$ reduction of one $\mathrm{Cu}$ centre to form a mixedvalence $\mathrm{Cu}^{\mathrm{II}} \mathrm{Cu}^{\mathrm{I}}$ species (wave $\mathbf{I}^{\text {red }}$ ) followed by the reduction of the second $\mathrm{Cu}$ centre to yield the corresponding $\mathrm{Cu}^{\mathrm{I}} \mathrm{Cu}^{\mathrm{I}}$ complexes (wave $\mathbf{I I}^{\text {red}}$ ).



Scheme 2

No oxidation has been detected, for any of the complexes, by a first anodic sweep without a previous reduction scan, indicating that neither a metal centred nor a ligand-centred oxidation is observed.

The electrochemical behaviour of the symmetrical macrocyclic dicopper(II) complexes $\mathbf{1}$ and $\mathbf{2}$ is consistent with that previously reported for other related symmetrical and unsymmetrical binuclear copper(II) complexes $[9,10]$.

Comparison of the $\mathrm{Cu}^{\mathrm{II}} / \mathrm{Cu}^{\mathrm{I}}$ redox potentials in various solvents showed a good correlation between half-wave potentials and the solvent electron pair donation ability, being the most negative potential recorded in DMSO and DMF and the less negative in NCMe [11,12], as observed in the present study.

The observation of the two distinct reduction waves $\mathbf{I}^{\text {red }}$ and $\mathbf{I I}^{\mathbf{r}}{ }^{\mathrm{i}}$ is indicative of an electronic communication between the two metals, which is reflected on the half-wave potential difference and the comproportionation constant $K_{\mathrm{c}}$ i.e. the equilibrium constant of reaction (eq. 1), which is given by the expression $K_{\mathrm{c}}=$ $\exp \left(\left|n_{1} E^{\mathrm{o}}{ }_{1}-n_{2} E_{2}^{\mathrm{o}}\right| \mathrm{F} / \mathrm{RT}\right)=\exp \left(\left|n_{1} E^{\mathrm{o}}{ }_{1}-n_{2} E^{\mathrm{o}}\right| / 25.69\right)\left(\right.$ at $298 \mathrm{~K}$, with $E^{\mathrm{o}}$ in $\left.\mathrm{mV}\right)$ [13].

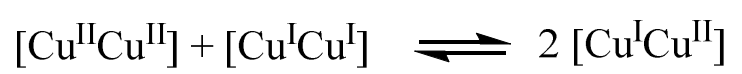

In our case, for the reversible processes, $n_{1}=n_{2}=1$ electron, $\left|E^{\mathrm{o}}{ }_{1}-E^{\mathrm{o}} 2\right|=\mid{ }^{\mathrm{I}} E_{1 / 2}{ }^{\mathrm{ox}}$ - ${ }^{\mathrm{II}} E_{1 / 2}{ }^{\mathrm{ox}} \mid=430 \mathrm{mV}$ (Table 1 ), leading to the high value of $K_{\mathrm{c}}=1.9 \times 10^{7}$, indicative of a Robin-Day class III system [14,15]. This shows a strong electronic interaction between the two metals, via the bridging groups and a high stabilization of the mixed-valence $\mathrm{Cu}^{\mathrm{I}} \mathrm{Cu}^{\mathrm{II}}$ state.

The comproportionation constant value observed for our bimetallic copper complexes $\mathbf{1}$ and $\mathbf{2}$ is in the range of the $K_{\mathrm{c}}$ values observed for other Robson type macrocyclic dicopper(II) complexes $\left(5.1 \times 10^{7}<K_{\mathrm{c}}<2.4 \times 10^{12}\right)[16,17]$. Comparing the $K_{\mathrm{c}}$ value obtained for the system under study with the one for other bimetallic systems studied by us, we can conclude, for example, that the interaction between the copper centres in $\mathbf{1}$ and $\mathbf{2}\left(K_{\mathrm{c}}=1.9 \times 10^{7}\right.$, in DMf or DMSO) is stronger than that observed between molybdenum centres, via bridging pyridylpyrazolate groups, in $\left[\text { cis- }\left\{\mathrm{Mo}\left(\eta^{3} \text {-allyl }\right)(\mathrm{CO})_{2}\left(\mu^{2}-\mathrm{pypz}\right)\right\}\right]_{2}\left(K_{\mathrm{c}}=\right.$ $1.2 \times 10^{6}$, in $\mathrm{CH}_{2} \mathrm{Cl}_{2}$ ) [18] or between iron centres in the dinuclear iron(II)hydride complex with a bridging nitrile $\left[\left\{\mathrm{FeH}(\mathrm{dppe})_{2}\right\}_{2}(\mu-\mathrm{LL})\right]\left[\mathrm{BF}_{4}\right]_{2}(\mathrm{LL}=$ $\mathrm{NCCH}=\mathrm{CHCN}$; dppe $\left.=\mathrm{Ph}_{2} \mathrm{PCH}_{2} \mathrm{CH}_{2} \mathrm{PPh}_{2}\right)\left(K_{\mathrm{c}}=1.6 \times 10^{3}\right.$, in $\left.\mathrm{CH}_{2} \mathrm{Cl}_{2}\right)$ [19]. 
Although 1 and $\mathbf{2}$ exhibit almost identical reduction potentials (the differences are only of $c a$. $0.04 \sim 0.05 \mathrm{~V}$ ), there appears to occur a minor systematic difference.

The less very slightly cathodic reduction potential of $\left[\mathrm{Cu}_{2} \mathrm{~L}\left(\mathrm{H}_{2} \mathrm{O} \text {.phen }\right)_{2}\right]\left(\mathrm{ClO}_{4}\right)_{2}$ $\mathbf{1}$, in all organic solvents used in this study, in comparison with that of the parent $\left[\mathrm{Cu}_{2} \mathrm{~L}\left(\mathrm{H}_{2} \mathrm{O}\right)_{2}\right]\left(\mathrm{ClO}_{4}\right)_{2} 2$, indicates a slightly lower electron-donor character of the ligands present in $\mathbf{1}$ relatively to those present in $\mathbf{2}$. This behaviour is in agreement with the expected [20] effect in solution of H-bond interaction, in 1, of the 1,10-phenanthroline molecules with the water ligands as revealed by X-ray crystallography of $\mathbf{1}$ in the solid state [8].

Moreover, such a minor difference of reduction potentials between $\mathbf{1}$ and $\mathbf{2}$ is not consistent with the replacement, in solution, of the ligated water in $\mathbf{1}$ by phenanthroline ligands, in contrast to what some spectroscopies studies [8] have suggested.

In fact, considering the markedly higher value of the electrochemical Lever $E_{\mathrm{L}}$ parameter (the higher this value, the weaker is the ligand electron-donor character) [21-24] for 1,10-phenanthroline ( $E_{\mathrm{L}}=0.26 v s$. NHE) in comparison with that of $\mathrm{H}_{2} \mathrm{O}(0.04$ vs. NHE), a considerably less cathodic reduction potential would be expected for $\mathbf{1}$, more significant than that observed.

Hence, our electrochemical results are consistent with the possible preservation in solution of the interaction of 1,10-phenanthroline with copper(II) through the coordinated water molecules, and disagree with its direct coordination to the metal.

This study could also provide an opportunity to estimate the $E_{\mathrm{L}}$ ligand parameter for the new Robson type macrocyclic ligand $\mu$-11,23-dimethyl-3,7,15,19tetraazatricyclo-[19.3.1.19,13,21] heptacosa-1(24),2,7,9,11,13(26),14,19,21(25), 22-decaene-25,26-diol (L) by applying the Lever Equation (eq. 2) [24], which relates linearly the redox potential ( $E$ in $\mathrm{V} v s$. the standard hydrogen electrode (SHE)) of an octahedral complex with the sum $\left(\Sigma E_{\mathrm{L}}\right)$ of the $E_{\mathrm{L}}$ ligand parameters for all the ligands (2-electron donors, assuming additive contributions).

$$
E=S_{\mathrm{M}}\left(\Sigma E_{\mathrm{L}}\right)+I_{\mathrm{M}} / \mathrm{V} v s . \mathrm{NHE}
$$

However, the slope $\left(S_{\mathrm{M}}\right)$ and the intercept $\left(I_{\mathrm{M}}\right)$, which are dependent upon the metal, redox couple, spin state and stereochemistry [24], are not know for the present redox couples and therefore the determination of the $E_{\mathrm{L}}$ ligand parameter was precluded.

\section{Experimental}

The electrochemical experiments were performed on an EG\&G PAR 273A potentiostat/galvanostat connected to a personal computer through a GPIB interface. Cyclic voltammetry (CV) studies for $\mathbf{1}$ and $\mathbf{2}$ were undertaken in $0.2 \mathrm{M}$ $\left[{ }^{n} \mathrm{Bu}_{4} \mathrm{~N}\right]\left[\mathrm{BF}_{4}\right] /(\mathrm{DMSO}, \mathrm{DMF}, \mathrm{NCMe}, \mathrm{MeOH}$ or EtOH $)$, at a platinum disc working electrode $(\mathrm{d}=0.5 \mathrm{~mm})$ and at room temperature. Controlled-potential 
electrolyses (CPE) were carried out in electrolyte solutions with the above mentioned composition, in a three-electrode H-type cell. The compartments were separated by a sintered glass frit and equipped with platinum gauze working and counter electrodes. For both $\mathrm{CV}$ and $\mathrm{CPE}$ experiments, a Luggin capillary connected to a silver wire pseudo-reference electrode was used to control the working electrode potential. A Pt wire was employed as the counter-electrode for the CV cell. The CPE experiments were monitored regularly by cyclic voltammetry, thus assuring no significant potential drift during the electrolyses. The solutions were saturated with $\mathrm{N}_{2}$ by bubbling this gas before each run, and the redox potentials of the complexes were measured by $\mathrm{CV}$ in the presence of ferrocene as the internal standard, and their values are quoted relative to the SCE by using the $\left[\mathrm{Fe}\left(\eta^{5}-\mathrm{C}_{5} \mathrm{H}_{5}\right)_{2}\right]^{0 /+}$ redox couple $\left(E_{1 / 2}^{\mathrm{ox}}=0.45 \mathrm{~V}\right.$ vs. SCE for NCMe, $\mathrm{MeOH} ; E_{1 / 2}^{\mathrm{ox}}=0.48 \mathrm{~V}$ vs. SCE for DMF, $E_{1 / 2}^{\mathrm{ox}}=0.48 \mathrm{~V}$ vs. SCE for DMSO) $[25,26]$.

\section{Acknowledgements}

This work has been partially supported by the Fundação para a Ciência e a Tecnologia (FCT), Portugal, including the postdoctoral fellowship SFRH/BPD/76451/2011 (attributed to S.A.) and the project UID/QUI/00100/2013.

\section{References}

1. Ramakrishnan S, Rajendiran V, Palaniandavar M, et al. Inorg Chem. 2009;48:1309-1322.

2. Ramakrishnan S, Shakthipriya D, Suresh E, et al. Inorg Chem. 2011;50:6458-6471.

3. Goswami TK, Chakravarthi VSKB, Roy $M$, et al. Inorg Chem. 2011;50:8452-8464.

4. Lim MH, Lau IH, Barton JK. Inorg Chem. 2007;46:9528-9530.

5. Tjioe L, Joshi T, Forsyth CM, et al. Inorg Chem. 2012;51:939-953.

6. Anbu S, Kandaswamy M. Inorg Chim Acta. 2012;385:45-52.

7. Anbu S, Kandaswamy M, Kamalraj S, et al. Dalton Trans. 2011;40:73107318.

8. Anbu S, Killivalavan A, Alegria ECBA, et al. J Coord Chem. 2013;66:3989-4003.

9. Anbu S, Suthakaran MKP, Murugan V, et al. J Inorg Biochem. 2009;103:401-410.

10. Okawa H, Tadokoro M, Aratake Y, et al. J Chem Soc, Dalton Trans. 1993;253-258.

11. (a) Mayer U., Gutmann V. Struct Bonding. 1972;12:113-140.

(b) Marcus Y. J Solution Chem. 1984;13:599-624.

12. Taraszewska J, Zieba K, Kowalski J, et al. Electrochim Acta. 2007;52:3556-3567.

13. Richardson DE, Taube H. Inorg Chem. 1981;20:1278-1285. 
14. Robin MB, Day P. Adv Inorg Chem Radiochem. 1967;10:247-422.

15. Brunschwig BS, Creutz C, Sutin N. Chem Soc Rev. 2002;31:168-184.

16. (a) MohantaS, Baitalik S, Dutta SK, et al. Polyhedron. 1998;17:2669-2677.

(b) Mandal SK, Nag K. J Chem Soc, Dalton Trans. 1884;2141-2149.

(c) Mohanta SK, Nanda KK, Werner R, et al. Inorg Chem. 1997;36:46564664.

17. Zhan S, Miao Y, Li P, et al. Transition Met Chem. 1996;24:311-316.

18. Arroyo M, Miguel D, Villafañe F, et al. J Chem Soc, Dalton Trans. 2012;41:7017-7025.

19. Venâncio AIF, Kuznetsov ML, Guedes da Silva MFC, et al. Inorg Chem. 2002;41:6456-6467.

20. Carvalho MFNN, Galvão AM, Pombeiro AJL. J Chem Soc, Dalton Trans. 2000;3393-3400.

21. Guedes da Silva MFC, Pombeiro AJL. Electrochim Acta 2012;82:478-483.

22. Pombeiro AJL. Eur J Inorg Chem. 2007;1473-1482.

23. Pombeiro AJL. J Organometal Chem. 2005;690:6021-6040.

24. (a) Lever ABP. Inorg Chem. 1991;30:1980-1985.

(b) Lever ABP. Inorg Chem. 1990;29:1271-1285.

(c) http://www.chem.yorku.ca/profs/lever/elparameter98.htm.

25. Pombeiro AJL, Guedes da Silva MFC, Lemos MANDA. Coord Chem Rev. 2001;219:53-80.

26. Silva MENPRA, Pombeiro AJL, Fraústo da Silva JJR, et al. J Organometal Chem. 1991;421:75-90. 